\title{
Social Differentiation and Spatial Mixture in a Transitional City - Kunming in
}

\section{Southwest China}

\author{
Prof. Qiyan Wu, \\ The Center for Modern Chinese City Studies \& School of Urban and Regional Science, East China Normal \\ University, Shanghai, China \\ Urban Studies Program, Simon Fraser University, Vancouver, BC, Canada \\ qywu@re.ecnu.edu.cn \\ Dr. Jianquan Cheng 1,2,* \\ ${ }^{1}$ Key Laboratory of Beibu Gulf Environmental Change and Resources Utilization under Ministry of \\ Education, Guangxi Teachers Education University, 175 Mingxiudonglu Road, Nanning, China \\ ${ }^{2}$ School of Science and the Environment, Manchester Metropolitan University, UK \\ Chester Street, Manchester, M1 5GD, UK \\ Prof. Craig Young \\ 1 School of Science and the Environment, Manchester Metropolitan University, UK \\ cyoungmmu@googlemail.com
}

Abstract:

Socio-spatial segregation, and particularly racial and ethnic segregation, has been extensively studied in the Western context but is less researched for Chinese cities, particularly those in less developed regions. The city of Kunming in remote southwest China is characterized by a transition from a socialist manufacturing center to a free market service economy and the strong presence of a diversity of ethnic groups. Kunming provides an opportunity to examine the similarities and disparities in the socio-spatial landscape compared to well-developed cities in China and other post-socialist contexts as well as those in the West. In this paper, population census data at the community level from 2000 together with its spatial boundary data are used to create 39 demographic, educational, occupational and housing variables for 431 communities. Principal component analysis, hierarchical clustering and spatial segregation indicators are combined in order to identify, classify and analyse the spatial segregation of diverse social groups. The study finds that, unusually for Chinese cities, ethnic minority and gender are significant factors, and it demonstrates that both spatial mixture and social differentiation simultaneously characterize Kunming.

Keywords: Spatial Mixture, Social Differentiation, Community, Ethnic Minority, Gender, Kunming. 


\section{Introduction}

Socio-spatial segregation has long been a focus of analysis in Western cities (Musterd and Ostendorf, 2013), such as the classical orientation of the Chicago school and its diverse foci on racial segregation, educational stratification and social division (Massey and Denton, 1993; Jenkins et al., 2008). In recent years, it has also become the focus of analyses in new contexts characterized by fundamental political, economic and social transformations with implications for the spatial segregation of social groups during rapid urbanization. One key example is the postsocialist countries of the former Eastern Europe, where geographers have attempted to assess the impact of the rapid marketization of society on urban social segregation (eg. Golubchikov, et al., 2014).

Given the extraordinary growth in Chinese cities and the fundamental shifts in China's political economy, China is another key context in which these issues are being analysed (Wu et al., 2014; $\mathrm{Gu}$ et al., 2005; $\mathrm{Wu}, 2005 ; \mathrm{Wu}$ and $\mathrm{He}, 2005)$. The substantial transformation of the Chinese economy since the beginning of free-market reforms has created one of the most dynamic and rapidly expanding urban systems in the world. Studies of the larger and more developed cities in the east (notably Beijing, Shanghai, Guangzhou, and Nanjing) have identified that socio-spatial differentiation is a feature of Chinese cities and is undergoing dynamic change as part of this urbanization (Wang et al., 2012; Gu et al., 2005; Li and Wu, 2008; Wu et al., 2014).

These studies suggest that such Chinese cities - those exhibiting a high degree of spatial segregation due to the two dominant processes of the impact of the planned economy and the subsequent ongoing transformation to a free-market economy - demonstrate a different model of socio-spatial segregation from Western cities. However, what remains little understood is 1) whether such patterns are also typical in other Chinese cities in less developed areas; 2) whether these patterns emerged in the same time frame; and 3) if they are not and did not, what are their unique characteristics compared to larger Chinese cities in more developed areas?

To provide an original contribution to these debates, this paper presents an analysis of socio-spatial segregation in Kunming in southwest China - a provincial capital in a relatively remote and less well developed region. The next section reviews key case studies of socio-spatial segregation in Chinese cities. Section Three describes the case study area, the data used and the analytical 
methods applied. Section Four presents the results of the analysis and interprets the patterns revealed. Section Five aims to develop a theoretical model based on the findings. The paper ends with some general conclusions on the implications of the findings for understanding segregation in Chinese cities more generally.

\section{Social differentiation and spatial mixing in transitional Chinese cities}

During over three decades of rapid growth, China has had to confront a restless, endogenous social stratification driven by neoliberal marketization (Harvey, 2005). Wu (2003) argued that these neoliberal pro-growth practices caused social-spatial transformation characterized by social differentiation and geographical segregation. While a small number of newly-emerging urban rich took advantage of marketization and the transformation of State-Owned Enterprises (SOEs) and Collective-Owned Enterprises (COEs) in the 1980s, a large proportion of their former employees became the jobless poor. At the same time, accelerated urbanization attracted new types of migrants, such as farm workers, rich mine owners and international immigrants.

Urban structure and morphology also changed but retained something of a mixed character as market-based urbanism reshaped an urban social geography based on the danwei system (Walks and Maaranen, 2008; Li et al., 2010; Wu et al., 2014; Li and Wu, 2008; Bray, 2005; Wu and Webster, 2011). Market-based urbanism involved a series of processes, which drove a complex mix of segregation and mixing. Urban sprawl produced suburbs with new residential areas, industrial zones and recreational parks. Many inner-city residents were either forcibly displaced by urban regeneration (Wu et al., 2014) or volunteered to move to suburbs to obtain more spacious housing and a more livable environment (a "rice-paddy" gentrification process - Waley, 2016). In a counter-process, many urban rich moved back to inner cities in a kind of revanchist urbanization, displacing inner-city blue collar workers from the bankrupt COEs and SOEs in the first wave of "slash-and-build" regeneration (particularly in large-sized coastal cities around the new millennium - Leaf, 1995). Furthermore, some culture- or education-based gentrification appeared in inner cities without physical change in the built environment, eg. gentrified communities of artists or "jiaoyufiers" (Harris, 2012; Wu et al., 2014; Wu et al, forthcoming). Meanwhile, a large number of farmers moved into urban villages for work (Gu et al., 2005; Liu and Wu, 2006; Chung, 2010). 
Therefore, at the new millennium, Chinese cities undergoing neoliberalist reform - from coastal areas to inland areas - more or less and sooner or later experienced this unprecedented social transformation $(\mathrm{Wu}, 2003)$. Both socio-economic stratification and its spatial disparity were spatio-temporally differentiated in the transition period (Fujita and $\mathrm{Hu}, 2001$ ). Consequently, Chinese urbanisation exhibited social change marked simultaneously by both differentiation and mixing.

In contrast to the four types of factors (discrimination, disadvantage, preferences, and social networks) identified as contributing to segregation in the Western context (Allen and Turner, 2012), transitional urban China demonstrated an inclusive complexity. This complexity is characterized by two sets of dual relationships between social stratification and social diversity and overall mixing but place-specific segregation at the local scale propelled by at least three sets of dialectic dual-structure forces.

First, segregation was shaped by the balance between the planned economy and market forces. The effect of socialist policies on the socio-spatial structure of Chinese cities is still significant (Madrazo and Van Kempen, 2012). The principle features of socialist-era urbanization are still present in most cities with danwei or work-unit housing and hukou status persisting as powerful forces in the housing market (Bray, 2005). Li and $\mathrm{Wu}$ (2008) highlighted the importance of socialist policies in shaping the socio-spatial structure of Shanghai in 2000 and Li et al. (2010) demonstrated that these forces were influential in the spatial structure of Guangzhou in 2000 which exhibited clear social area distinctions. However, the social-spatial structure of Beijing, Shanghai, and Guangzhou were more shaped by neoliberal global forces and market power ( $\mathrm{Gu}$ et al, 2005; Li et al., 2010; Li and Wu, 2008; Liu et al., 2014). Thus, in contrast, in some contexts the increasing role of market forces created socio-spatial segregation in part through the power of the housing market (Wang and Murie, 2000) and in part through the strong pull force of urban growth fueled by the development of a free-market-based neoliberal economy (Lin and Zhang, 2014).

Secondly, when housing became part of a real estate market, it also offered choice about a suitable location in which to live ( $\mathrm{Li}$ and $\mathrm{Wu}, 2008)$. In-migrants, because of cultural exclusion or local people's resistance, or due to their self-identification and self-protection in cultural reproduction as well as daily experiences, may group together giving rise to urban enclaves both in the innercities and suburbs (Li et al., 2009). Analogously, ethnic minorities also tend to live together for 
cultural reasons or self-identification when they move into new urban territory (Gu et al., 2005; Breitung, 2012), giving rise to different settlement patterns, e.g. ghettoes or enclaves (Mallee and Pieke, 2014).

Thirdly, the urban mosaics were also reshaped by the mixture of in-migrants with residence with existing residents for whom hukou register reform in the later 1980s meant a loosening of residential control (Chan and Zhang, 1999; Hu and Kaplan, 2001; Feng and Zhou, 2003). Thus, travel and interregional and intra-city migration became more possible. So, rural migrants swarmed into cities leading to the development of significant, identifiable and relatively poor segregated social areas in cities. This can be seen in the case of coastal-region cities, such as Beijing (Hu and Kaplan, 2001; Gu et al., 2005), Shanghai (Liu et al., 2014) and Nanjing (Wu et al., 2014). Meanwhile, the urban rich or dominant classes have gradually developed urban enclaves in traditional city-center or high-quality suburban residential zones and displaced the original poorer inhabitants ( $\mathrm{Wu}, 2001)$.

Therefore, with respect to social differentiation and spatial patterns, some differences emerged between Chinese coastal-region, developed areas and inland, less-developed areas. Chinese social transformation demonstrates regionalization (Giddens, 1984), differentiation in geography, or a disparity in the path-dependence of space production.

\section{Methodology}

\subsection{Study area}

Kunming is located in east-central Yunnan Province of which it is the capital. As the third largest city in south-west China (after Chengdu and Chongqin), Kunming administers six urban districts, four counties, three autonomous counties and one county-level city (Figure 1), with a total area of $21,012 \mathrm{~km}^{2}$. It is undergoing a transition from a socialist manufacturing center to a free market service economy with a focus on tourism and biochemicals and flower production (Wu et al., 2015). The effects of this shift, especially in the development of a commodity housing market, have only been seen relatively recently (Zhang, 2010).

The national population census data of 2000 reveal that among the 26 original Yunnanese minorities (Yang, 2009) residing in the Kunming city area, Yi, Bai and Hui are most abundant 
(11.2\% of the total population of Kunming), in contrast to other minority groups such as Dai and Sani (only $0.2 \%$ ). Bai, Yi, and Hui minorities have relatively higher levels of education, employment and income compared to other minorities (Postiglione, 2013), but most minority ethnic groups are entitled to some benefits according to China's Minority Policy. For example, they are able to legally have a second child under the strict regulation of national one-child family planning, and to keep their cultural traditions (eg. language and religious traditions) and have preference in higher education.

Since various urban reforms initiated in the mid-1990s (eg. the tax reform of 1994 and urban housing reform in 1995) market-led social space has been replacing the dominant danwei society. From around 2000, property-led redevelopment has contributed to the formation of many highstatus lake-view communities in the Cuihu Lake and Dianchi Lake areas.

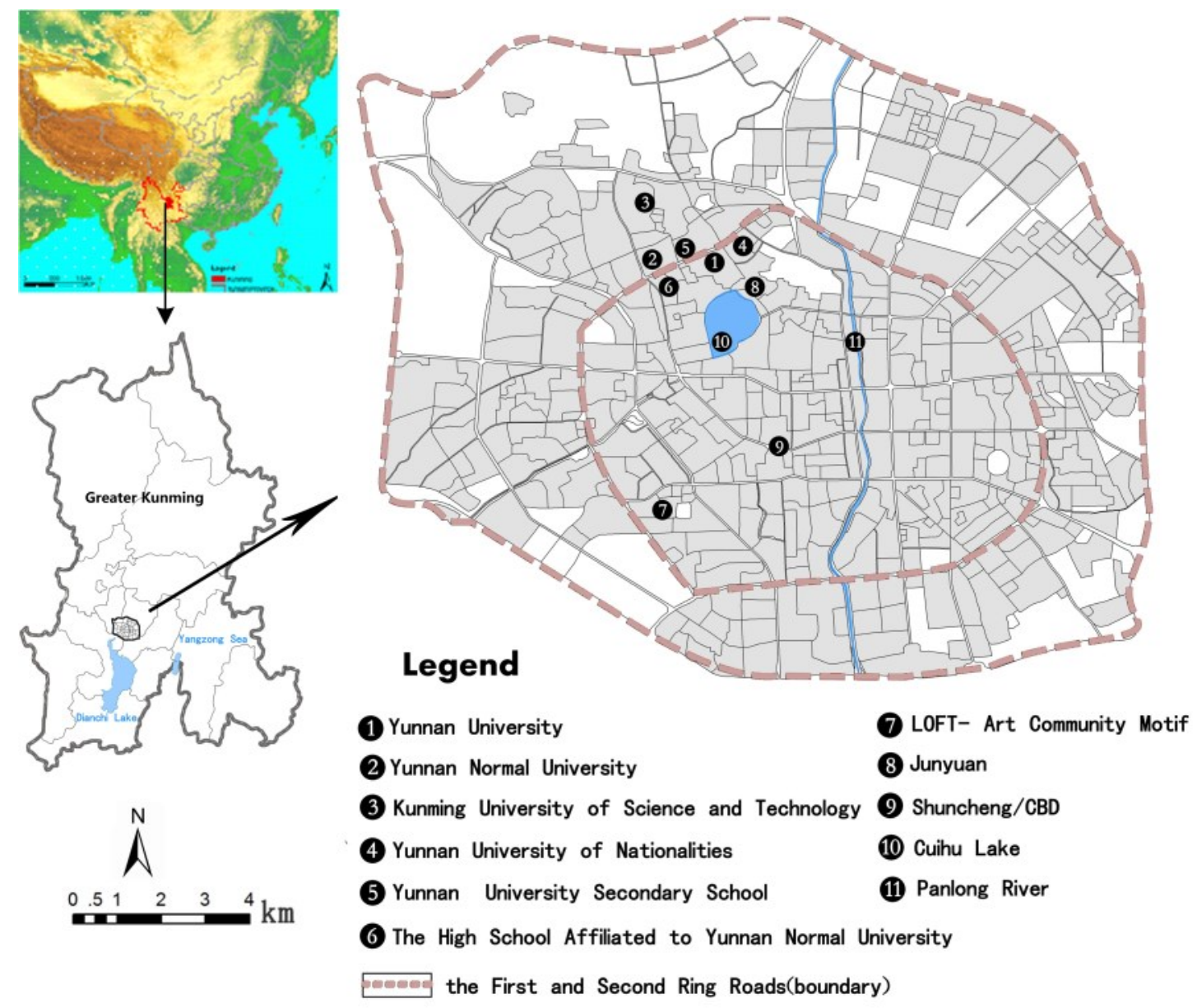

Figure 1. Location of Greater Kunming and its inner city 
Consequently, Kunming, as a city lagging significantly behind the major coastal-region cities in the shift toward a services economy, provides a good choice for a comparative case study using the same data set. Gu et al. (2005) on Beijing, Li et al. (2010) on Guangzhou at sub-district level, $\mathrm{Li}$ and $\mathrm{Wu}$ (2008) on Shanghai at non-geo-referenced community level, and Wu et al. (2014) on Nanjing at geo-referenced community level, all use the 2000 census data as it remains the key dataset for this type of analysis. Therefore, it is reasonable to expect that analysis of Kunming will reveal the impact of ethnicity as well as the effect of temporal-spatial lag on Chinese neoliberal urban development.

\subsection{Data and methods}

The inner city of Kunming is composed of 27 sub-districts and 431 communities, which are located within the second ring road or beltway of Kunming (Figure 1) with a population of 922,144 (16.0\% of the total population of Greater Kunming) and a total area of $34 \mathrm{~km}^{2}$ in 2000 . The city area of Kunming is evenly and densely covered by a radial road network. Its central business district (CBD) and geographical centers are situated around Shuncheng. The higher education institutions are mostly concentrated in the Northwest, and its old airport and manufacturing industry in the East. Dianchi Lake and Expo Park are located in the South and North respectively. As socioeconomic differentiation is the principal determinant of residential segregation in Chinese cities (Wu and Webster, 2010), the following three categories of variables, similar to those used for case studies of Guangzhou (Li et al., 2010) and Nanjing (Wu et al., 2014), are employed in this case study: (1) demographic characteristics; (2) occupational characteristics; and (3) housing. In total 39 variables reflecting these three dimensions have been selected and applied to the 431 communities for further statistical and spatial analyses (Table 1).

In this case study, a mixed method approach using index- and statistical analysis-based methods is adopted for social and spatial analyses, specifically principal components analysis (PCA), hierarchical clustering and spatial segregation analyses. PCA is a well-established data exploration tool used to reduce large data sets into a more manageable and interpretable number of highly independent components. This method, together with clustering methods, has been extensively utilized for analysing socio-spatial segregation in the case study of Nanjing (refer to Wu et al. 
(2014) for more details). Therefore, a hierarchical cluster approach is applied based on Ward's minimum variance method (Gu et al., 2005). The combination of these two methods enables the identification and classification of social groups.

The third method - Geo-Segregation Analyzer (Apparicio et al., 2013), an open source software for calculating residential segregation indices - provides 43 indices for measuring the five dimensions of geographical segregation ie. evenness, exposure, concentration, clustering and centralization. From these indices, four measures - Segregation index (IS), Isolation index $(x P x)$, Absolute clustering index $(A C L)$ and Mean proximity between members of group X (Pxx) (see the detailed descriptions in Appendix 1) - are selected to calculate evenness (IS), exposure ( $x P x)$, and clustering $(A C L, P x x)$ and particularly to compare the degree of spatial segregation between all the clustered areas or communities. The selection of the four indices is based on a number of iterations exploring which better distinguishes the clustered social areas. The combination of three methods enables the integration of spatial and statistical data into social and spatial analysis.

\section{Results}

The following section presents and interprets the results from the three inter-related analyses: PCA components, clustering of social areas and comparison of indicators of spatial segregation between these clusters.

\subsection{PCA components}

The PCA of the 39 variables for the 431 communities yields 12 components using a Promax rotation method with 25 iterations, which explains 72.23 percent of the total variance (Appendix 2). The 12 components identified and shown in Figure 2 can be used to delineate the sociodemographic structure of Kunming and form the basis of understanding its socio-spatial segregation in the inner city. 

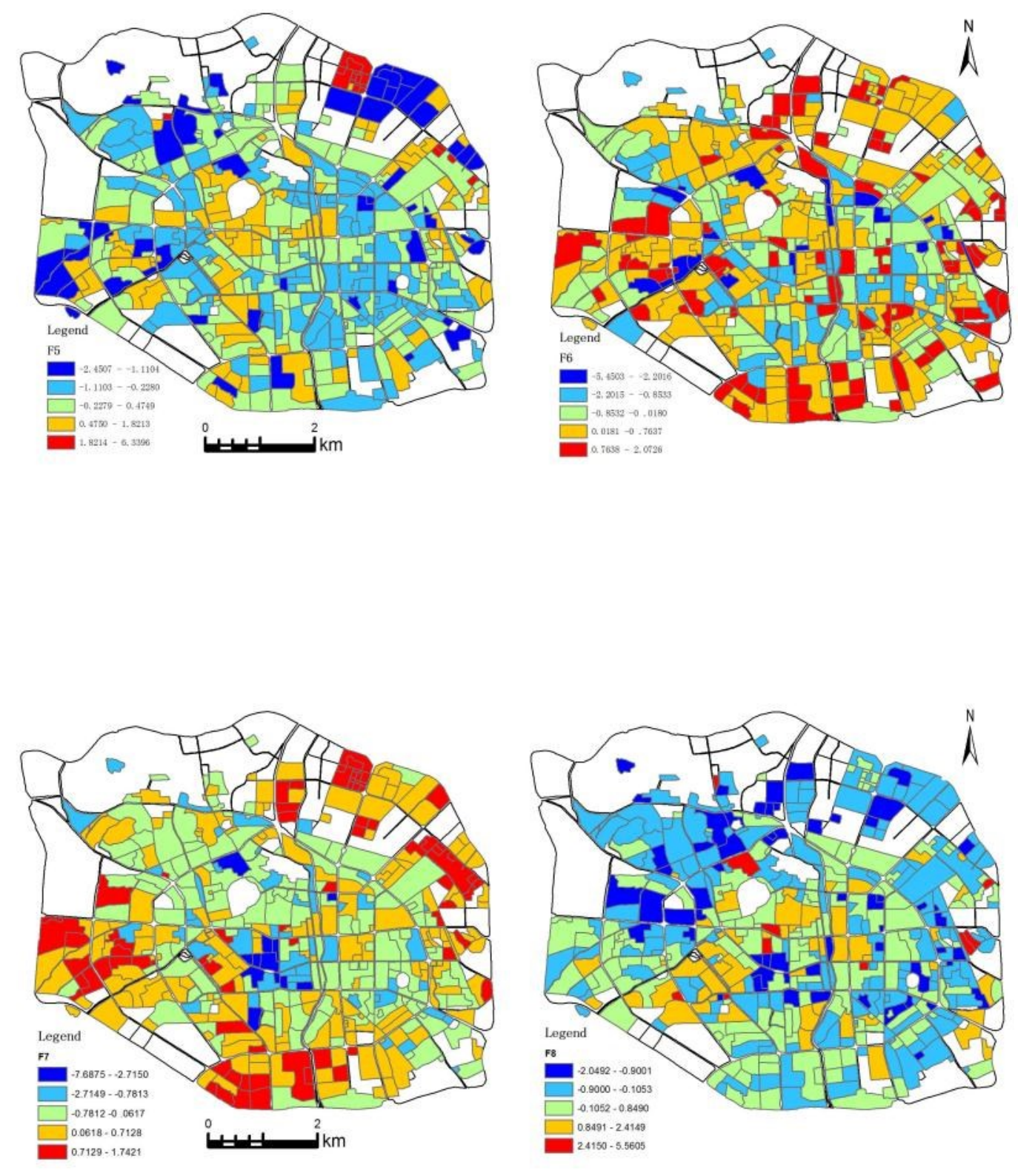

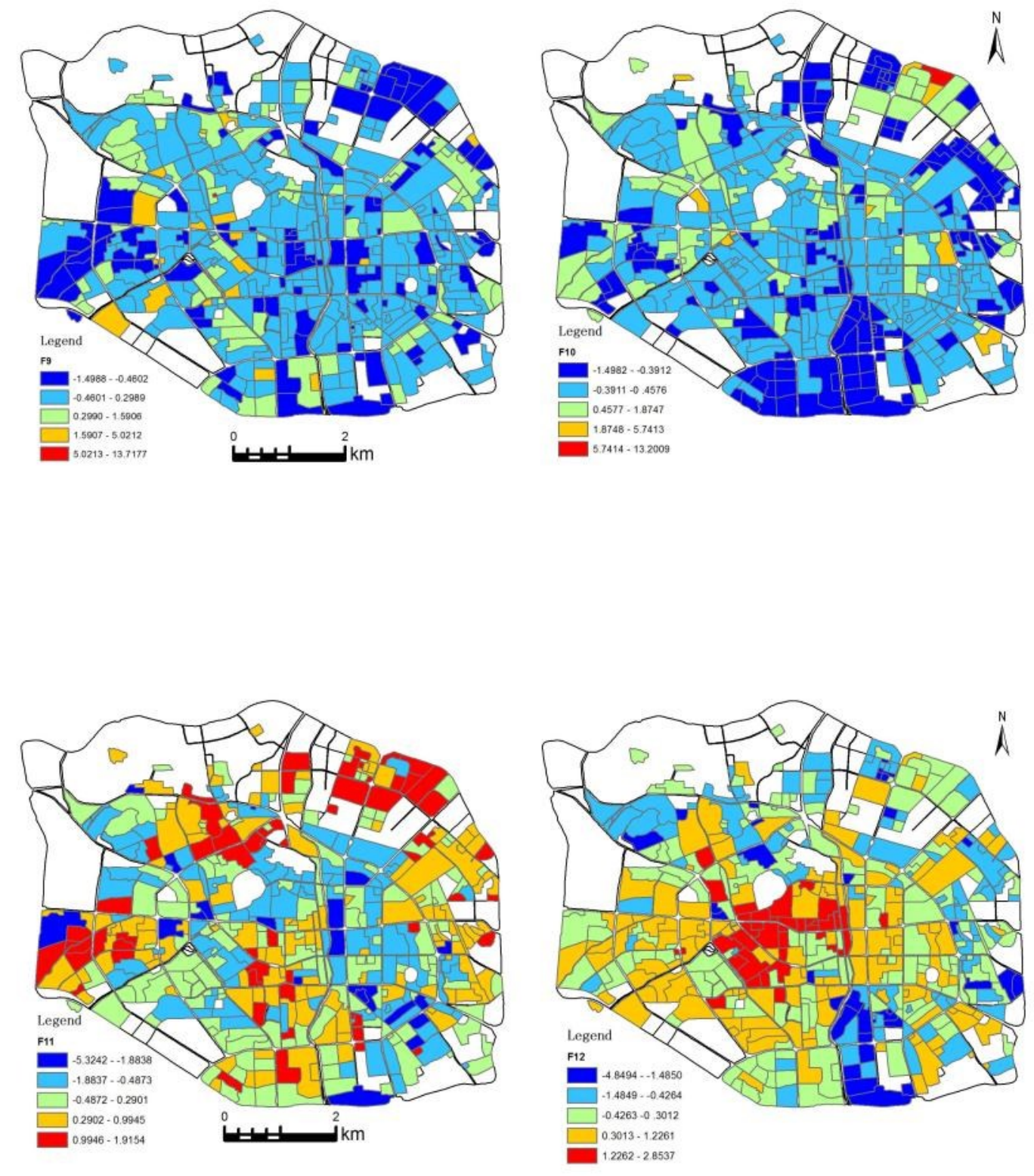

Figure 2. Spatial distribution of the 12 main components 
Component I: minority professionals. This component is primarily distinguished by highly positive correlations with the ethnic (principal component loading $=0.343,1.4 \times$ Standard Deviation (SD)), higher education $(0.630,1.7 \times \mathrm{SD})$, careers in professional $(0.746,2 \times \mathrm{SD})$ and cadre variables (0.272). Much of the housing in the areas that fall into this component (Figure 4) is large and relatively new and much of it was purchased from former public housing stock by private owners (0.741). While it consists of quality housing it is not at the upper end of the housing quality spectrum.

Component II: small families (-0.816) with young children (0.662). In a previous study of Nanjing city, $\mathrm{Wu}$ et al. (2014) identified a similar social group which they termed jiaoyufication (“educationisation"), by which they meant a new form of gentrifying group located around high quality primary and secondary schools, used by families (eg. grandparents) with school-age children. However, by comparison, this component in Kunming also contains another social group ie. adults aged 30-59 whose proportion is a little bit higher than in Nanjing. As in the case of Nanjing (see Wu et al., 2014), housing quality in this component is not high, but families with young children and a higher level of income have moved to these areas because of their children's or grandchildren's education. Good quality schools in Kunming are mostly located in the old city within the first beltway or the northern area within the second beltway, while more mixed groups of residents locate in the south or around the second beltway.

Component III: mortgage slaves. This component is characterized by a high proportion of quality housing (0.717) and a low rate of newly-built affordable housing (0.162) with relatively high proportions of young couples (aged 15-29, 0.292) and couples with children (0.337). This relatively high proportion can be explained by a feature of Chinese society which emerged in the late 1990s, the trend towards "marriage housing", meaning that bridegrooms are required by brides' families to purchase a housing unit and sometimes a car before the wedding. In this situation most young couples have to arrange a mortgage with banks and repay the high-rate interests throughout their lives.

Component IV: female minority professional. This social group is distinguished by a relatively high level of higher education (0.492) and professional (0.652), as both of these have highly negative correlations with male $(-0.540,1.8 \times \mathrm{SD})$, Han ethnic group $(-0.337,1.4 \times \mathrm{SD})$ and other career sectors $(-0.898)$. 
Component V: upper class. This is defined as cadre (0.683) and the high-level professional managerial class. Many of the latter work in the lucrative finance, insurance and real estate sectors (0.344) and some tend to live in newer housing (0.250). They purchased the highest quality commercial housing $(0.728)$ at a relatively lower price $(0.267$, compared to mortgage slave, 0.717$)$.

Component VI: ordinary citizen. A small percentage of this group have good higher education qualifications $(0.248,0.4 \mathrm{xSD})$ and some are professional $(0.162)$ or government clerical workers (0.162).

Component VII: female clerical workers. These tend to work in the lucrative finance, insurance and real estate sectors, or in government.

Component VIII: government clerical workers. These typically live in new and high-rise residential buildings.

Component IX: affordable housing residents (0.785). Many of these live by part-time employment, for they are highly correlated with other sectors $(0.771)$ and have a low correlation with any other careers.

Component X: landless farmers or rural in-migrants in urban enclaves. These mostly live in old and low quality self-build housing (0.666).

Component XI: mixed residents. Professionals in the lucrative finance, insurance and real estate sector or in retail.

Component XII: clerical workers, mostly in the lucrative finance, insurance and real estate sectors.

Compared to Beijing, Shanghai, Guangzhou and Nanjing, Kunming is characterized by many minor nationalities and this uniqueness is reflected in components I and IV which show a strong correlation with ethnicity. Moreover, a further difference in Kunming is that the three components I, IV and XI clearly exhibit negative or positive correlations with gender and thus display particular relationships between gender and urban form (Tacoli and Satterthwaite, 2013) which are not observed in other Chinese cities. These components imply that the social space of Kunming differs from cities such as Nanjing or Shanghai at community level. 


\subsection{Clusters of social groups}

Cluster analysis enables more detailed exploration of the spatial relationships between these social structures and the identification of distinct social areas. Through a hierarchical clustering method, the 431 communities (or juweihui) were grouped into eight primary clusters (Table 1, Figure 3).

Table 1. Identification of clusters

\begin{tabular}{|c|c|c|c|c|c|c|c|c|c|c|c|c|c|}
\hline Cluster & Total & $\mathbf{I}$ & II & III & IV & $\mathbf{V}$ & VI & VII & VIII & IX & $\mathbf{X}$ & $\mathbf{X I}$ & XII \\
\hline $\begin{array}{l}\text { Mixed female and } \\
\text { minority professional }\end{array}$ & 74 & 0.065 & 0.041 & 0.026 & 0.046 & 0.028 & 0.030 & 0.085 & 0.018 & 0.019 & 0.009 & 0.034 & 0.038 \\
\hline $\begin{array}{l}\text { Fading urban } \\
\text { civilians }\end{array}$ & 128 & 0.023 & 0.021 & 0.011 & 0.024 & 0.065 & 0.033 & 0.039 & 0.014 & 0.014 & 0.032 & 0.033 & 0.020 \\
\hline $\begin{array}{l}\text { Intellectuals and } \\
\text { cadres }\end{array}$ & 33 & 0.123 & 0.039 & 0.052 & 0.074 & 0.058 & 0.085 & 0.092 & 0.129 & 0.079 & 0.096 & 0.141 & 0.054 \\
\hline $\begin{array}{ll}\text { Fading } & \text { downtown } \\
\text { common } & \text { civil and } \\
\text { clerks } & \end{array}$ & 33 & 0.089 & 0.024 & 0.069 & 0.068 & 0.054 & 0.153 & 0.110 & 0.151 & 0.065 & 0.102 & 0.043 & 0.101 \\
\hline $\begin{array}{l}\text { Mixed ordinary } \\
\text { civilians, traditional } \\
\text { upper class and } \\
\text { Intellectuals }\end{array}$ & 58 & 0.077 & 0.047 & 0.026 & 0.039 & 0.074 & 0.015 & 0.079 & 0.054 & 0.015 & 0.082 & 0.065 & 0.086 \\
\hline $\begin{array}{l}\text { Traditional upper } \\
\text { class }\end{array}$ & 15 & 0.258 & 0.121 & 0.218 & 0.228 & 0.333 & 0.227 & 0.247 & 0.183 & 0.123 & 0.113 & 0.186 & 0.334 \\
\hline $\begin{array}{l}\text { Affordable housing } \\
\text { and renting area }\end{array}$ & 27 & 0.092 & 0.078 & 0.137 & 0.130 & 0.081 & 0.059 & 0.062 & 0.091 & 0.148 & 0.035 & 0.140 & 0.077 \\
\hline New urban elite area & 63 & 0.040 & 0.054 & 0.091 & 0.053 & 0.087 & 0.021 & 0.095 & 0.010 & 0.029 & 0.056 & 0.057 & 0.055 \\
\hline
\end{tabular}




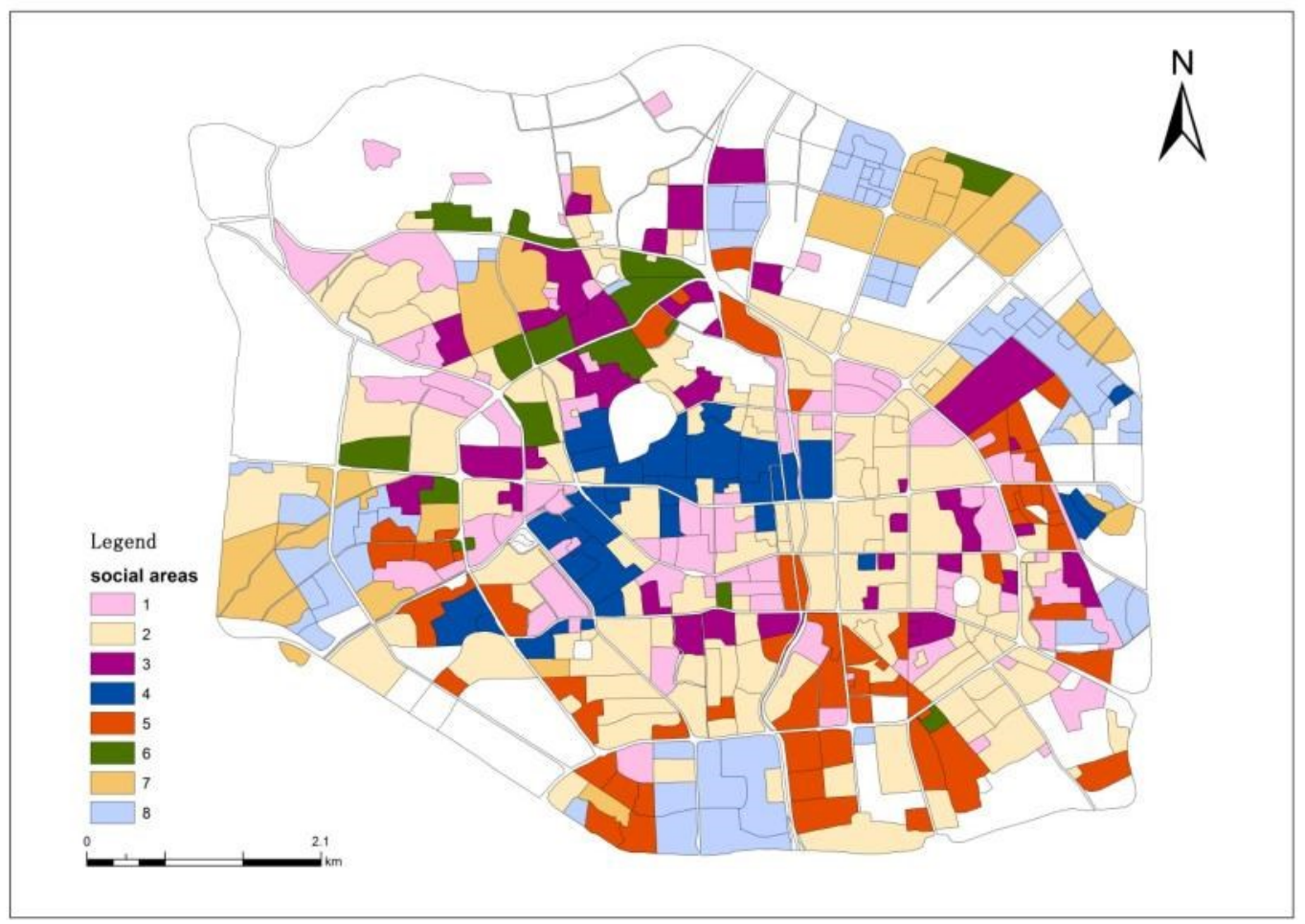

Figure 3. Clusters identified

Our first cluster is the second largest social group which is composed of 74 communities and has a moderate level of correlation with three components (Table 1). Female clerk (VII) shows the strongest relationship, but minority professionals (IV) and female minority professional (I) components also contribute. With the inclusion of these three components, this cluster is labeled as 'mixed female and minority professional'. Primarily, the mixed middle and slightly higher status are located in these communities. The spatial pattern of these areas is complex, but there are three main areas of concentration. The largest one is situated in the northwest of the old city which was traditionally occupied by upper and middle status neighborhoods and its east neighbourhood was an elite area in the early 1900s (Figures 1 and 3). The second largest concentration sits in the west of the commercial center. The third is located eastward around the second beltway, which is a newly developed suburban district. The northwestern concentration contains the majority of higher education institutions (Figure 1). Some municipal offices or agencies were located on the eastern side of new suburban areas. Field observation at selected inner-city areas suggests that there has been some redevelopment and gentrification since the 1990s. 
Many universities and SOEs are located in this cluster with a high proportion of privately-owned and rented public housing sub-clusters evenly distributed. But these two sub-clusters have a relatively high degree of segregation compared with the other types. For example, the mean value of IS for renting commercial housing units is $0.61(0.25 \times \mathrm{SD})$ and for purchasing commercial housing units $0.77(0.52 \times \mathrm{SD})$. Therefore the scale of clustering is small as IS is high but ACL is low and most sub-clusters are embedded into public housing (cluster) with a high degree of segregation. Self-build housing has the highest degree of segregation with an IS value of 0.82 $(1.35 \times \mathrm{SD})$ and is concentrated in suburban areas.

The second cluster has the largest area encompassing 128 communities and is characterized by high correlations with the cadre (V) and moderate correlations with female clerk (VII) and ordinary citizen (VI, XI) components. With the inclusion of these components, this cluster is labelled as 'fading ordinary citizen', meaning areas where the previous ordinary residents were displaced or replaced. Part of this cluster is located around Cuihu Lake and comprises of a large proportion of cadre residents, some of whom are 'ordinary citizens', particularly in the south and east of the first beltway or old city wall (Figure 3).

Within this cluster, a renting and particularly purchasing public housing sub-cluster predominates ( $75 \%$ of the total) but it is less diverse ( $\mathrm{ACL}=0.73, \mathrm{xPx}=0.78$ ). The incidence of renting commercial housing sub-clusters is comparatively low $(\mathrm{IS}=0.92, \mathrm{ACL}=0.01)$ and sparsely distributed within public housing sub-clusters with a high degree of mixing $(\mathrm{xPx}=0.02)$.

The third cluster area, 'intellectual and cadre', is substantially smaller than the previous two, but also has moderate correlations with several components. Although it is not the most elite area of the city, this cluster is populated by higher-level white-collar workers, many of whom are cadres and some are professional and technical workers. There is also a stronger correlation with the housing component, indicating that most of the housing sub-clusters in these areas have been fully regenerated (Appendix 2). Interestingly, there is a correlation between this housing component and the lake-view elite villa areas of Kunming of the early 1900s near Cuihu Lake. The spatial structures are differentiated between the two periods (1990s and 2000s), but the cluster area remains attractive for gentrification by higher status residents. In this cluster, reform houses form a much higher proportion of the housing stock (75\%) and with a very homogeneous distribution $(\mathrm{ACL}=0.73,2.23 \times \mathrm{SD} ; \mathrm{xPx}=0.78,2.14 \times \mathrm{SD})$. In comparison, renting commercial houses is only 
small scale $(\mathrm{IS}=0.92,1.06 \times \mathrm{SD} ; \mathrm{ACL}=0.01,0.5 \times \mathrm{SD})$ and with sporadic distribution and a high degree of mixing $(\mathrm{xPx}=0.02,0.68 \times \mathrm{SD})$.

The fourth cluster area has the third largest number of communities and moderate correlations with two components: ordinary citizen (VI) and governmental clerk (VIII). This area is primarily located around the center of old Kunming, including a number of old villa sub-clusters, and the areas with an original housing style. Given the general wealth of these areas and the number of professionals living there, we identify these areas as 'fading ordinary citizen' area. This refers to communities undergoing changes from planned-economy based, danwei-led, common communities to market-led increasingly divided neighborhoods in urban areas and downtown areas respectively. The dominant housing in this cluster is purchasing reform housing sub-clusters $(57 \%$ of the total), which are relatively homogeneously clustered $(\mathrm{xPx}=0.67)$, with a small proportion of new commercial housing sub-clusters $(\mathrm{ACL}=0.05)$.

The fifth cluster area has much weaker correlations with its components. The most significant correlation is with clerical worker in lucrative sectors (XII), urban enclave (X), and female clerical workers (VII). This area is concentrated in the south of the old city. Some of these areas were rehabilitated in the pre-market era and while much of the housing is modern it is not large or elite and mostly rented rather than owned. As such, it is certainly a mixed civil servants area. Public housing (purchasing and renting) is the dominant type in this cluster with a proportion of $80.3 \%$, a large-scale and a homogeneous distribution ( $\mathrm{xPx}=0.69$ for purchasing and 0.23 for renting). $\mathrm{By}$ contrast, commercial housing is heterogeneously mixed with others (IS $=0.55$ for purchasing commercial houses and 0.48 for renting these houses). Self-build (IS 0.77) and affordable housing (IS 0.54 ) are only sporadically distributed across the cluster.

The sixth cluster exhibits moderate correlations with female clerical workers (VII), upper class (V) and minority professionals (I), indicating that these areas house moderate status bureaucrats with a mixture of a few higher status individuals (Figure 3). These areas are relatively concentrated in the northwest of the inner-city which was traditionally a cluster of upper class residents. The dominant housing in this cluster is reform housing ( $63.85 \%$ of the total), forming a certain scale of clusters (IS for renting reform housing sub-clusters $=0.38$ and purchasing the sub-clusters $=0.58$ ) and their distribution is relatively homogeneous (xPx for renting reform housing sub-clusters $=0.29$ and purchasing the sub-clusters $=0.70$ ). There is a very small presence of commercial housing 
(5.25\%) and affordable housing (4.5\%) sparsely distributed among the reform housing sub-clusters (eg. IS for renting and purchasing commercial housing sub-clusters $=0.78$ and 0.89 , with the ACL values $=0.25$ and 0.02 respectively, and IS for purchasing affordable housing sub-clusters $=0.73$ with the ACL value=0.20).

The seventh cluster area has strong correlations with the affordable housing residences (IX), mixed ordinary citizens (XI) and mortgage slave (III) and particularly the exposure degree and clustering of commercial renting has been maximized and accordingly a large-scale new development zones can be seen in this cluster. Hence, it is better referred to as the 'affordable housing and renting area'. This cluster is dominated by a certain scale of mixed sub-clusters of renting commercial housing (IS=0.27) and self-build (IS=0.17). In addition, affordable housing is sparsely distributed with $\mathrm{IS}=0.68$ and $\mathrm{ACL}=0.03$.

The eighth cluster demonstrates a stronger correlation with a set of components including middleupper status and high-quality housing, as it is labeled as the 'new elite area'. Given its high correlations with female clerical workers in lucrative finance (VII), mortgage slave (III) and upper class components (V), this area is highly clustered at the four corners just outside the second beltway (Figure 3). Historically, this cluster has not been a particularly prestigious area, but much of the area was cleared for commodity housing which is now a mix of large apartments, villas and some modern high-rises. In this cluster, both purchasing commercial houses and reform houses form a large proportion of the total $(20.83 \%$ and $36.32 \%$ respectively), located in the outer suburban districts in the form of clustering and mixture but they are less mixed with each other (xPx and ACL for purchasing commercial house $=0.43$ and 0.21 and xPx and ACL for purchasing reform houses $=0.50$ and 0.22 ).

Additionally, among the eight social areas of Kunming, the reform housing and rented public housing components demonstrate a strong influence on the pattern of housing tenure in Kunming with an average value of $49.2 \%$ and $18.5 \%$ in 2000 respectively.

\section{Discussion}

Compared to studies of Nanjing (Wu et a., 2014) and Guangzhou (Li, 2010) using the same data, the Kunming case study reveals two key differences. 


\subsection{Neoliberal differentiation in a southwest transition city with an ethnic minority factor}

During Kunming's period of transition it has exhibited a neoliberal-driven social polarization. This is particularly seen within the 'fading urban civilians' cluster, particularly those factory communities or neighbourhoods constructed during the planned economy stage south and east of the first beltway (Figure 4). Subsequently, the former co-worker relationship that existed within the danwei system between manager and worker was rapidly divided into employer and employee, new rich and jobless blue-collar workers, following privatization of SOEs or COEs in the 1990s.

However, what marks Kunming as different to the Han-dominated large coastal-region cities is that ethnic minorities have a strong influence (Wong, 2000). Probably as a consequence of longterm integration between non-Han and Han, ethnic minorities have played a significant role in Kunming's social composition. For instance, both the principal components I (minority professionals) and IV (female minority professional), and their social clusters, eg. the area of mixed female and minority professional (I), are characterized by ethnic factors that not only play a pivotal role in the urban geography but also demonstrate a high degree of social-spatial integration. In fact, the presence of traditional Islamic shops in the CBD demonstrates that these minorities had a significant impact on the urban built environment in Kunming which is distinctive from the coastal-region cities. Meanwhile, Bai and Yi minorities have a relatively high presence

in the higher education sector (eg. Yunnan Minority University) and bureaucratic positions, and accordingly make significant contributions to social clusters I and VI.

\subsection{Spatial mixing: a transitory stage before segregation?}

In contrast to the looming market-led social differentiation, the urban geography of transitional Kunming was less well defined at the turn of new millennium. As the most multiethnic city in China, Kunming's urban geography was shaped by a diversity of ethnic enclaves, which may be caused by the path-dependent legacies of space production under the planned economy. That is, the emergence of the segregation pattern lagged behind these social-spatial differentiation processes.

First of all, the spatial mixture was caused by the interaction of danwei-driven forces and 
increasing market forces, similar to the mixture of path-dependencies and transition-induced factors of former East European post-socialist cities (Golubchikov et al., 2014). The largest mixed female and minority professional cluster located in the northwest, for example, contained both danwei-based new-build dormitories and market-led gentrified neighbourhoods (eg. those near Cuihu Lake). Certainly, these urban enclaves (especially the gentrified neighbourhoods) - and even the ethnic enclaves (eg. the campus of Yunnan Minority University) - are neither completely sociospatially exclusive nor completely separate from the previous arrangement of danwei in the planned economy (Bray, 2005). On a smaller scale, in fact, they are gated communities bounded by the red brick walls of danwei, while at a larger scale, they are relatively integrated into the social area, where non-Han minority students, faculties, and officials are relatively dominant groups.

Moreover, the property-led inner-city regeneration and pro-growth suburban new-build also contribute to the mixed urban mosaic, while displacing inner-city old blue collar and land-loss farmer respectively. Because Kunming has received relatively little foreign direct investment (FDI) and suffers from a shortage of development capital in the less developed areas, the pace of revanchist urbanism (Smith, 2002) in Kunming was slower, or regeneration was blocked by pathdependent institutional arrangements. For instance, the accumulated FDI during 1995-2000 only amounted to $64 \%$ of the average provincial level in China. Consequently, it gave rise to a model of gradual revanchist urbanism rather than a rapid slash-and-build gentrification as was the case in more developed cities at the same stage. Subsequently, urban diversity increased when a large number of new-build areas were inserted into the older patterns.

Based on the 2000 census data set and present-day field survey, the urban geography of Kunming has been driven by at least four types of displacement during diversification from the dominant danwei-based urban landscape to a neoliberalist divided space in 2000 (Waley, 2016):

(1) Some small-scale tower-block gentrification (Lützeler, 2008) appeared in the intellectual and cadre cluster around the Cuihu Lake area within the old inner-city of Kunming in later 1990s. This did displace the original lower class on small scale, while rich gentrifiers returned to the innercity and penetrated into former upper class residential areas through a gradual revanchist urbanism. However, the large-scale, slash-and-build gentrification, eg. market-led, new-build gentrification characteristic of Western countries (Davidson and Lees, 2010) or state-led, new-build 
gentrification in Chinese coastal-region cities around 2000s, did not occur in Kunming at this stage.

(2) Aestheticized gentrification also occurred in the inner city through the reuse of old buildings as upmarket restaurants and boutiques (Broudehoux, 2007), which also displaced a limited number of original blue-collar workers, increasing the diversity of the inner-city rather than the degree of segregation. More interestingly there has been the appearance of a gentrification of artist neighbourhoods (Harris, 2012) caused by artists occupying the former blue-collar worker neighborhoods in South Kunming for galleries and bars.

(3) The rich purchased apartments within the catchment of the best primary and secondary schools in Kunming located around Yunnan University campus, leading to the displacement of the lower class, and gradually formed a "jiaoyufication" neighbourhood (Wu et al., 2015).

(4) A few large-scale, exclusive, new-build "rice-paddy gentrification" areas (Waley, 2016) appeared in the suburbs (Figure 4), displacing a large number of farmers in a similar way that urban sprawl created "land loss farmers" as in other Chinese cities (Zhou and Ma, 2000).

These types of displacement did not increase the exclusivity of the inner-city on a large scale in a short span of time. However, they did start to squeeze the lower class out of the city through a gradual revanchist urbanism or slowly reshaping the inner-city social space. Therefore, the Kunming case does not demonstrate that it is exceptional in China's neoliberal urban transition. However, it is a localised case (or regionalization in Giddens' (1984) concept) of the urban socialspatial shift of China, which is caused by a pair of dialectic dynamics - institutional lock-in or path-dependence of danwei on the one hand (Golubchikov et al., 2014), and neoliberal space production on the other (Madrazo and van Kempen, 2012). The lack of investment capital in this remote less-developed area has made the case of Kunming more complex and positioned it as more gradually on the way to neoliberal transition.

Therefore, though using the same census data, the PCA analysis from this case study created more primary components than were produced for market-led coastal cities in the same period, eg. Guangzhou (Li et al., 2010, using similar data at sub-district level), Beijing (Gu et al., 2005, using less detailed data), and Nanjing (Wu et al., 2014, using the same data set but resulting in a smaller number of primary components). Such disparities reflect and further endorse the findings that lessdeveloped, inland cities such as Kunming demonstrate some traits of a slow transition from a 
planned economy based urban society to being market-oriented post-reform cities. Since Kunming demonstrates such mixed characteristics and less clearly observable patterns and trends more primary components are required in the PCA to interpret its complex socio-spatial patterns.

\section{Conclusions}

This paper presents a unique case study of socio-spatial segregation in Kunming, a less developed city in southwestern China, in order to compare urbanization in that context to more wellestablished understandings of the changing urban geography of relatively well-developed coastal cities in China.

The remarkable contribution of ethnic minorities to the formation of social clusters and urban landscapes revealed demonstrates that minorities are playing an increasingly more important role in the formation of complex social mosaics in Kunming than in Chinese coastal-region cities ( $\mathrm{Gu}$ et al., 2005).

Moreover, in contrast to these coastal cities, Kunming presents a paradoxical relationship between the rates of neoliberalist social differentiation and urban restructuring, in which the reformation of urban space lags behind social differentiation. This social-spatial mismatch is shaped by the interaction of numerous factors including the nature of gradual revanchist urbanism, policies towards ethnic minorities, market forces, danwei housing from the socialist era, the lack of capital for large-scale regeneration, and the historical urban morphology. Therefore, the mosaic of smallscale segregated areas (eg. gated communities and tower-block gentrification) in a mixed district may reflect an early phase of socio-spatial shift, which indicates the slow and ongoing process of neoliberal urbanization in the less-developed regions of China.

Furthermore, the socio-spatial analysis reveals that women have played a significant role in the spatial pattern of social clusters of mixed female and minority professional and new urban elite areas of Kunming, which may be caused by the relatively high proportion of female employees in the higher education sector or businesses within the above-mentioned clusters, but their contribution to the socio-spatial pattern requires further exploration.

Finally, Kunming has been developing much faster since 2000 compared to the late twentieth century due to the national development strategy of accelerating neoliberal reforms in inland cities. 
For example, rapid urbanization in the new-build Chenggong District in the East since the early 2000s and the large-scale re-generation/gentrification of its inner city in the 2010s have displaced these 'fading social areas' significantly (Wu and Waley, forthcoming). As a result, there is an urgent call for continuing empirical studies of Kunming and other inland cities in Western and Central China to support the development of new urban theories, rather than using the theoretical frameworks developed from the study of well-developed coastal cities, to highlight different dynamics in residential segregation, particularly gender and ethnicity.

\section{Acknowledgements}

The research is supported by National Natural Science Foundation of China (Nos. 41271176 \& 41671155) , and open fund of Key Laboratory of Beibu Gulf Environmental Change and Resources Utilization under Ministry of Education (No. 2015BGERLKF06).

\section{References}

Allen, J.P. \& Turner, E., (2012) Black-White and Hispanic-White segregation in U.S. counties. Professional Geographer, 64 (4): 503-520.

Apparicio, Philippe, Éric Fournier and Denis Apparicio (2013) Geo-Segregation Analyzer: a multiplatform application (version 1.1). Montreal, Spatial Analysis and Regional Economics Laboratory (SAREL), INRS Urbanization Culture Société.

Bray, D. (2005) Social space and governance in urban China: The Danwei system from origins to reform. Palo Alto: Stanford Univ Press.

Breitung, W. (2012) Enclave urbanism in China: Attitudes towards gated communities in Guangzhou. Urban Geography, 33(2): 278-294.

Chan, K.W. \& Zhang, L. (1999) The hukou system and rural-urban migration in China: Processes and changes. The China Quarterly, 160: 818-855.

Davidson, M., and Lees, L. (2010) New-build gentrification: its histories, trajectories, and critical geographies, Population, Space and Place, 16: 395-411.

Dickson, B.J. (2007) Integrating wealth and power in China: the communist party's embrace of the private sector. China Quarterly, 192: 827-854. 
Giddens, A. (1984) The constitution of society: Outline of the theory of structuration. Univ of California Press.

Golubchikov, O., Badyina, A. \& Makhrova, A. (2014) The hybrid spatialities of transition: Capitalism, legacy and uneven urban economic restructuring. Urban Studies, 51(4): 617-633.

Gu, C., Wang, F. \& Liu, G. (2005) The structure of social space in Beijing in 1998: a socialist city in transition. Urban Geography, 26(2): 167-192.

Harris, A. (2012) Art and gentrification: pursuing the urban pastoral in Hoxton, London. Transactions of the Institute of British Geographers, 37(2): 226-241.

Jenkins, S. P., Micklewright, J., \& Schnepf, S. V. (2008). Social segregation in secondary schools: how does England compare with other countries?. Oxford Review of Education, 34(1): 2137.

Johnston, R., Poulsen, M., \& Forrest, J. (2007) The geography of ethnic residential segregation: A comparative study of five countries. Annals of the Association of American Geographers, 97(4): 713-738.

Le Goix, R. (2005). Gated communities: sprawl and social segregation in Southern California. Housing studies, 20(2), 323-343.

Li S., Hou, Q., Chen, S., \& Zhou, C. (2010) Work, home, and market: The social transformation of housing space in Guangzhou, China. Urban Geography, 31(4): 434-452.

Li, Z., \& Wu, F. (2008) Tenure-based residential segregation in post-reform Chinese cities: a case study of Shanghai. Transactions of the Institute of British Geographers, NS 33: 404-419.

Li, Z., Ma, L.J.C. \& Xue, D. (2009) An African Enclave in China: The Making of a New Transnational Urban Space. Eurasian Geography and Economics. 50(6): 699-719.

Liu, Y., \& Wu, F. (2006) Urban poverty neighborhoods: typology and spatial concentration under China's market transition a case study of Nanjing. Geoforum, 37: 610-626.

Liu, Y., Dijst, M., \& Geertman, S. (2014) Residential segregation and well-being inequality between local and migrant elderly in Shanghai, Habitat International, 42: 175-185.

Lützeler, R. (2008) Population Increase and" New-Build Gentrification" in Central Tōkyō. Erdkunde, 287-299.

Madrazo, B., \& van Kempen, R. (2012) Explaining divided cities in China. Geoforum 43: 158168.

Mallee, H., \& Pieke, F. N. (2014) Internal and international migration: Chinese perspectives. 


\section{Routledge.}

Massey, D. S., \& Denton, N. A. (1988) The dimensions of residential segregation. Social Forces, 67 (2): 281-315.

Massey, D. S., \& Denton, N. A. (1993) American Apartheid: Segregation and the Making of the Underclass. Harvard University Press.

Musterd, S., \& Ostendorf, W. (Eds.). (2013) Urban segregation and the welfare state: Inequality and exclusion in western cities. Routledge.

National Statistical Bureau of China (NSBC) (2011) China Statistic Yearbook. Beijing, National Statistical Press of China.

Postiglione, G. A. (Ed.). (2013) China's national minority education: Culture, schooling, and development. Routledge.

Smith, N. (2002) New globalism, new urbanism: gentrification as global urban strategy. Antipode, 34(3): 427-450.

Tacoli, C. \& Satterthwaite, D. (2013) Gender and urban change. Environment and Urbanization, 25(3): 3-8.

Van Kempen, R., \& Murie, A. (2009) The new divided city: changing patterns in European cities. Tijdschrift voor economische en sociale geografie, 100(4): 377-398.

Waley, P. (2016) Speaking gentrification in the languages of the Global East. Urban Studies, 53(3): 615-625.

Walks, R. A., \& Maaranen, R. (2008) Gentrification, social mix, and social polarization: Testing the linkages in large Canadian cities. Urban Geography, 29(4): 293-326.

Wang, D. Li, F. \& Chai, Y. (2012) Activity space: a new perspective of socio-spatial segregation in Beijing, China. Urban Geography, 33 (2): 256-277.

Wang, Y. P. \& Murie, A. (2000) Social and spatial implications of housing reform in China. International Journal of Urban and Regional Research, 34: 397-417.

Wong, D. W. (2000) Ethnic integration and spatial segregation of the Chinese population. Asian Ethnicity, 1(1): 53-72.

Wu, F. (2003) The (post-) socialist entrepreneurial city as a state project: Shanghai's reglobalisation in question. Urban Studies, 40(9): 1673-1698.

Wu, F., \& He, S. (2005) Changes in traditional urban areas and impacts of urban redevelopment: a case study of three neighborhoods in Nanjing China. Tijdschrift voor Economische en 
Sociale Geografie, 96(1): 75-95.

Wu, F., \& Webster, C. J. (Eds.). (2010) Marginalization in urban China: Comparative perspectives. UK: Palgrave Macmillan.

Wu, Q., Cheng, J., Chen, G., Hammel, D. \& Wu, X. (2014) Socio-spatial differentiation and residential segregation in the Chinese city: based on the 2000 community-level census data: a case study of the inner city of Nanjing. Cities 39: 109-119.

Wu, Q., Cheng, J., Liu, D., Han, L., and Yang ,Y. (2015) Kunming - A Regional International Mega city in Southwest China" in Urban Development Challenges, Risks and Resilience in Asia Mega Cities edited by R.B. Singh. Springer.

Wu, Q., and Waley, P.,(forthcoming) Configuring growth coalitions among the projects of urban aggrandizement in Kunming, southwest China. Urban Geography.

Wu, Q., Zhang, X., and Waley, P. (2016) Jiaoyufication: When gentrification goes to school in the Chinese inner city. Urban Studies 53(12): 3510-3526.

Yang, B. (2009) Central state, local governments, ethnic groups and the minzu identification in Yunnan (1950s-1980s). Modern Asian Studies, 43(03): 741-775.

Zhang, L. (2010) In Search of Paradise: Middle-Class Living in a Chinese Metropolis. New York: Connell University Press. 